\title{
BRITTLENESS OF In ADDED Bi OXIDE
}

\author{
In 添加した Bi 系酸化物超伝導体の脆性
}

\begin{abstract}
Hiroyuki Izumi, Kaoru Usui, Nobutake Hirai, Yuichi Kawaguchi,
Hiroko Yamamoto, Kazuya Oguri and Yoshitake Nishi
\end{abstract}

Department of Materials Science, Tokai University, 1117 Kitakaname,

Hiratsuka, Kanagawa, 259-12 JAPAN

( Accepted for publication 17 November 1994)

\section{1. 緒言}

$\mathrm{Bi}$ 系酸化物超伝導体は $100 \mathrm{~K}$ 以上の高い 超伝導遷移温度（ $\mathrm{T}_{\mathrm{c}}$ ）を示すため、液体窒 素での使用が可能である。そのため将来有望 な材料として、その特性が様々な形で評価さ れている。1-3 しかし、この酸化物は脆く、加 工性が悪いという久点があり実用化に対して 大きな障害となっている。

一方、 $\mathrm{Bi}$ 系酸化物超伝導体の $\mathrm{Bi} 、 \mathrm{~Pb} 、 \mathrm{Cu}$ とイオン半径及び電気陰性度が近似している Inを添加することにより、その脆性を改善で きる可能性がある。そこで、本実験では Bi 系酸化物超伝導体にIn を置換する形で添加し、 どの程度脆性が改善されるか検討を行った。

\section{2. 害験方法}

1) 試料作成

試料の基本出発組成を $\mathrm{Bi}_{1.6} \mathrm{~Pb}_{0 .} \mathrm{Sr}_{2} \mathrm{Ca}_{2} \mathrm{Cu}_{3} \mathrm{O}_{\mathrm{x}}$ とし、 $\mathrm{Bi}_{2} \mathrm{O}_{3}, \mathrm{PbO}, \mathrm{SrCO}_{3}, \mathrm{CaCO}_{3}, \mathrm{Cu} 0$ の高純 度粉末を用いて、固相反応法により作製した。な お In の添加は $\mathrm{Ca}$ 側に一部置換する方法で行っ

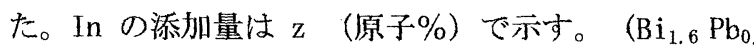
$\left.{ }_{4} \mathrm{Sr}_{2} \mathrm{Ca}_{2-\mathrm{z}} \mathrm{In}_{\mathrm{z}} \mathrm{Cu}_{3} \mathrm{O}_{\mathrm{x}}, 0<\mathrm{z}<0.2\right)$ アモルファス 試料の作製には、Figure 1 に示す双ピストン・ アンビル型急冷凝固装置を用いた。1,4

\section{2）脆性試験}

脆性の評価には島津製作所製超微小硬度計 （ DUH-50）を用いた。この装置は加える荷重を 連続的に変化させ、荷重と圧子の押し込み深さの 関係を求める装置である。測定時の最大荷重は $50 \mathrm{gf}$ であり、毎秒 $0.13 \mathrm{gf} / \mathrm{s}$ で $0 \mathrm{gf}$ から 増し、破壊が起こると応力が緩和され変曲点が現 れる。すなわち、この変曲点の現れた時にクラッ クが発生する。なお、このクラックが入った時の 荷重を( $\left.\mathrm{L}_{\mathrm{f}}\right)$ 、圧子の押し込み深さを $\left(\mathrm{h}_{\mathrm{f}}\right)$ とした。Figure 2 に $\mathrm{L}_{\mathrm{f}} 、 \mathrm{~h}_{\mathrm{f}}$ の定義図を示す。

ところで、 $\mathrm{L}_{\mathrm{f}} 、 \mathrm{~h}_{\mathrm{f}}$ だけでは、硬さの異なる材 料の評価は正しくできない。そこで、クラックの 形成に必要な変形エネルギー $\left(W_{\mathrm{f}}\right)$ 值で評価を 行った。 $W_{f}$ は式 1 より求めることができる。

$$
\mathrm{W}_{\mathrm{f}}=\mathrm{L}_{\mathrm{f}} \times \mathrm{h}_{\mathrm{f}} / 3
$$

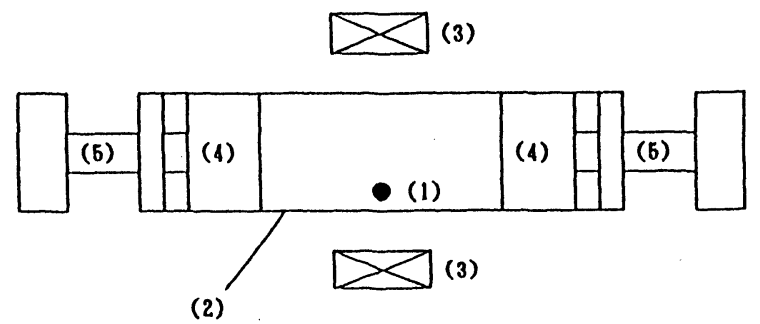

(1) Specimen

(4) Cu substrare

(2) Quartz tube

(5) Air piston

(3) Infrared furnace

Fig. 1 Twin-type piston-anvil apparatus. 


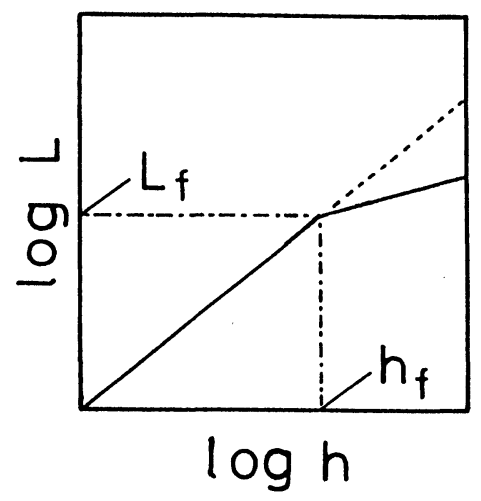

Fig. 2 Definition of $h_{f}$ and $L_{f}$.

3 . 結果及び考察

Figure 3 に In 添加量 $(\mathrm{z})$ とクラック 発生時の圧子の押し込み深さ $\left(\mathrm{h}_{\mathrm{f}}\right)$ の関係 を示した。 $z=0.1$ の試料において最大值を示 した。Figure 4 に In 添加量 $(\mathrm{z})$ とク ラック発生時の荷重 $L_{\mathrm{f}}$ の関係を示し $\mathrm{z}=0.1$ の試料において最大值を示した。Figure 5 に In 添加量 ( $\mathrm{z})$ とクラックが発生した 時の変形エネルギー $W_{\mathrm{f}}$ の関係示す。 $\mathrm{z}=0.1$ の試料のとき、 $W_{\mathrm{f}}$ は最大值を示し、最も大き な脆性の改善が見られた。ここで、Bi 系酸化 物超伝導体の脆さの原因が原子間の圧縮応力 場の形成によると仮定した場合、Caよりも イオン半径が小さいInを添加することによ り、圧縮応力場による歪みが緩和され、初期 クラックの発生が抑制されたと考えることが できる。一方、添加量を増すと脆性の低下が みられる。これは、イオン半径の小さな In を過剩に添加することにより圧縮応力の緩和 が飽和し、逆に引張り応力が生じクラックが 発生しやすくなったためと説明することがで きる。

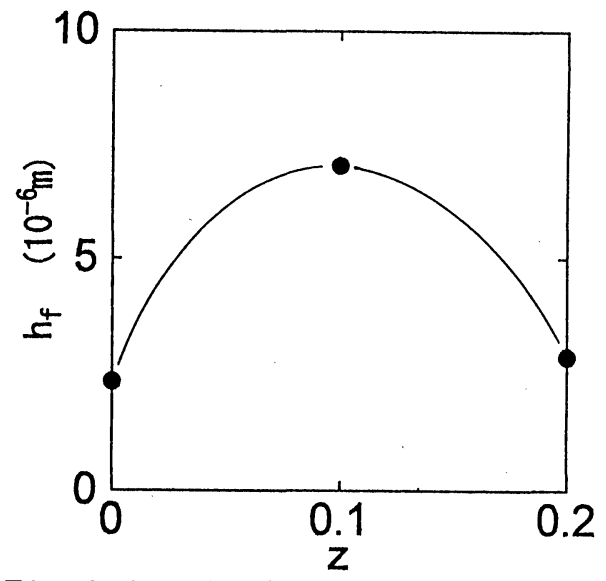

Fig. 3 Critical depth, $h_{f}$ vs. In concentration, $\mathrm{z}$ of $\mathrm{Bi}_{1.6} \mathrm{~Pb}_{0.4} \mathrm{Sr}_{2}$ $\mathrm{Ca}_{2-\mathrm{z}} \mathrm{In}_{\mathrm{z}} \mathrm{Cu}_{3} \mathrm{O}_{\mathrm{x}}(0 \leqq \mathrm{z} \leqq 0.2)$.

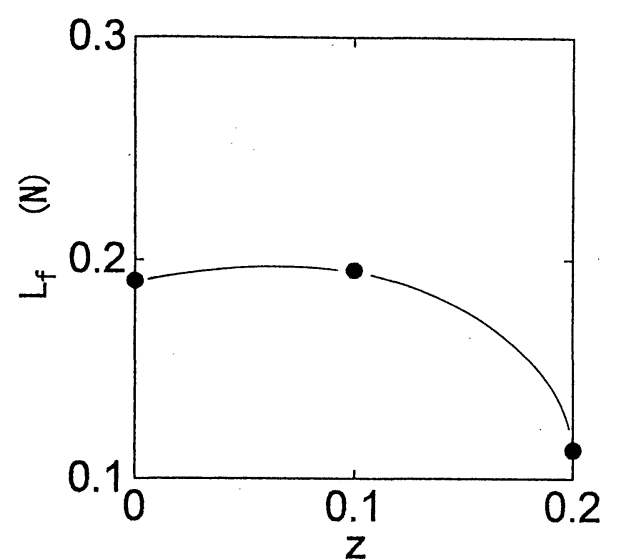

Fig. 4 Critical load, $\mathrm{L}_{\mathrm{f}}$ vs. In concentration, $\mathrm{z}$ of $\mathrm{Bi}_{1.6} \quad \mathrm{~Pb}_{0.4} \mathrm{Sr}_{2}$ $\mathrm{Ca}_{2-\mathrm{z}} \mathrm{In}_{\mathrm{z}} \mathrm{Cu}_{3} \mathrm{O}_{\mathrm{x}} \quad(0 \leqq \mathrm{z} \leqq 0.2)$.

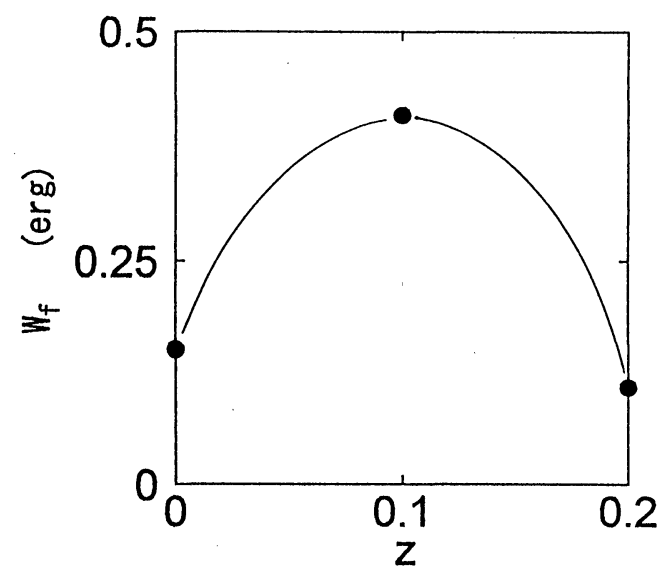

Fig. 5 Critical deformation energy, $\mathrm{W}_{\mathrm{f}}$ vs. In concentration, $\mathrm{z}$ of $\mathrm{Bi}_{1.6}$

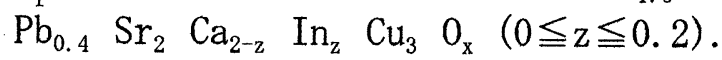

4. 結言

Bi 系酸化物超伝導体にイオン半径の小さな Inを添加することにより脆性の改善が見られ た。これは、圧縮応力場によって引きおこさ れていた歪みが In・の添加により緩和された ためと説明できる。

\section{REFERENCES}

1 Y.Nishi, S.Moriya, and T.Manabe, J. Appl. Phys. 65, 2389 (1989).

2 Y.Nishi, K. Oguri, H. Ohinata, K. Tanioka, Y.Kita, and N.Nioyama, Phys. Rev. B, 41 (1990) 6520

3 Y.Nishi, Y.Kita, and K. Tanioka, J. Mater. Sci. Lett. 7, (1990) 359.

4 T.Aida, K.Shiraisi, K.Oguri, and Y.Nishi, J. ADV. Sci. 5, 24 (1992) 